\title{
'The Curse of Knowledge': Reflections from a Teaching Practicum Course in a Saudi University
}

\author{
Afra Takrouni \\ The English Language Institute, King Abdulaziz University, Saudi Arabia \\ E-mail: atakrouni0005@stu.kau.edu.sa \\ Miriam Alkubaidi (Corresponding author) \\ The English Language Institute, King Abdulaziz University, Saudi Arabia \\ E-mail: malkubaidi@kau.edu.sa
}

Received: August 6, 2019 Accepted: September 26, 2019 Published: November 10, 2019

doi:10.5296/gjes.v5i2.15224 URL: https://doi.org/10.5296/gjes.v5i2.15224

\begin{abstract}
This paper is an action research study that focuses on improving the quality of my teaching practice as an English language teacher in an English as a foreign language (EFL) educational context. It presents my reflections as a post-graduate student of Master in Teaching English to Speakers of Other Languages (MA TESOL) from the Teaching Practicum course at a Saudi Arabian University. The study of Teaching Practicum course enabled me to develop my understanding of teaching as a profession, to reflect upon my pedagogical practice systematically, and to tackle teaching issues and concerns. Based on my reflective practice, this action research introduces the curse of knowledge as a pedagogical issue, which I have faced throughout this course as a student. As part of the study, lesson plans and reflective journals were used to obtain the required data through conducting four micro-teaching sessions. Newby's (2010) reflective cycle was followed to reflect on my teaching practice in a systematic way. As the data was thematically analyzed, I realized that the clarity of instructions played a significant role in decreasing the effect of the curse of knowledge on teaching. As a result, students were not be able to carry out classroom activities.
\end{abstract}

Keywords: Action Research, Teaching Practice, Lesson Plans, Reflective Journals, Teaching Practicum 


\section{Introduction}

Teaching practice offered me, as a student teacher, the opportunity to broaden my understanding of teaching as a profession and enhanced my teaching experience to improve its quality. During teaching practice, I was prepared to teach through setting learning objectives, planning lessons, revising materials, and selecting teaching techniques to achieve the desired outcomes. Besides, I was trained to handle the pedagogical challenges that occurred during my teaching practice in EFL classrooms.

Through the course of my study in the Teaching Practicum course, I faced various challenges that impeded the process of classroom teaching. One of the main sources of these challenges was the gap between the teacher and learners' minds. As a student teacher, I failed to explain the basics to my novice students regardless of how hard I tried. Based on the fact that teachers are more knowledgeable than students, I struggled to act in a way that took proper account of this knowledge difference. I could not put myself in my students' shoes and failed to imagine what it was like to lack knowledge; therefore, I assumed that the lesson content was clear and straightforward. The reason behind this phenomenon became clear to me when I was introduced to the curse of knowledge through the Teaching Practicum course materials.

In 1990, Elizabeth Newton, a psychological graduate at Stanford University, examined a simple task to illustrate the meaning of the curse of knowledge. In the experiment, Newton assigned participants to a single role either a 'tapper' or a listener. The 'tappers' were asked to pick a well-known song and tap out the rhythm with their fingers while the listeners had to figure out the title, based on the rhythm being 'tapped'. Approximately, 120 songs were 'tapped', but only 3 of them were figured out appropriately. Moreover, when the 'tappers' asked to estimate the probability that the listeners would be able to figure out the title of the given song correctly, they always overestimated. Newton noticed that the 'tappers' knew what they were 'tapping' and they assumed the listeners would be able to recognize it quickly. They could not imagine the situation from the perspective of the listeners because their knowledge had 'cursed' them.

In the same line of thought, Kennedy (1995) highlighted that the curse of knowledge was closely related to the 'hindsight bias' of increased knowledge of a topic. It influenced one's ability to predict how much knowledge others had. The curse of knowledge was therefore defined as the difficulty of recreating the state of mind due to the lack of knowledge (Heath \& Heath, 2007).

After understanding the concept of the 'Curse of Knowledge' and how it effects people's communication, I began to be encouraged to think about the way of giving instructions to the novice students. Hence, this action research study seeks to shed light on the curse of knowledge as a pedagogical issue that impedes the process of teaching in EFL classrooms. It presents several teaching techniques to cope with the curse of knowledge while at the same time, taking into consideration the Saudi educational context and its cultural aspects.

The next section highlights the importance of action research and the use of reflection in classroom-based research. The following provides detailed elaboration of the research setting 
and the employed research design, which is action research in order to elicit the required data. The findings and discussion section clarifies the main outcomes of the conducted action research cycles with my personal reflections on the implemented teaching techniques 'actions'. Based on the analysed data, I obtained different useful teaching techniques that supported me in handling the curse of knowledge in EFL classrooms. The last section of the paper offers suggestions for further investigations and recommends pedagogical implications in the light of the findings.

\section{Literature Review}

\subsection{What is Action Research and Why is it Important for Teachers?}

According to Ferrance (2000), action research is the 'discipline of inquiry' that is carried out by a teacher to investigate issues or concerns of a specific learning environment. In the same point of view, Kuhne and Quigley (1997) state that action research assists teachers to gain a deep understanding of an issue that requires changes or an area in needs of improvement, which directly enhances teachers' understanding of their teaching practices and the classroom situations. Literature shows that action research is recognized as a professional development research method for teachers who seek to broaden their knowledge of teaching and improve their teaching practices (Burns, 2009; Feldman, Altrichter, Posch, \& Somekh, 2018).

Action research supports teachers to gradually improve their practices as it allows them to act as researchers within their classrooms and the educational contexts (Hien, 2009). Accordingly, carrying out action research is valuable for teachers as long as the aim is continuous improvement in existing practices (Lesha, 2014). As researchers, teachers begin an action research cycle by identifying a practical problem that needs to be tackled through creating a set of actions to be examined during teaching practices (Feldman, Altrichter, Posch, \& Somekh, 2018). Based on the findings revealed from a cycle, various circumstances may occur that require further investigation in a new cycle (Ferrance, 2000). Throughout the ongoing process of action research cycles, teachers reflect deeply on their teaching practices by pursuing changes or improvement according to the circumstantial challenges (Hien, 2009).

\subsection{The Use of Reflection in Classroom}

The primary goal behind conducting action research is that teachers dedicate time to think about their teaching practices and situations in which these practices are carried out in the form of self-reflection (Carr \& Kemmis, 1986). Reflection offers teachers the opportunity to think back on a lesson and examine its phases; what went well, what did not and why with the main focus on evaluating the teaching experience (Richards, 1995). Reflective teaching is therefore defined as a systematic process that enables teachers to explore their teaching practices by thinking on how they delivered a lesson to engage in an ongoing improvement process (Mathew, Mathew, \& Peechattu, 2017). Additionally, reflective teaching is recognized as the teachers' ability to explore their teaching practices from or through their own experiences (Finlay, 2008; Göker, 2012). In the light of the above-mentioned definitions, it is understood that reflective teachers are more aware of themselves and their teaching practices; therefore, they work towards their personal professional development and improvement (Fakir, 2015). To 
understand the notion of reflective teaching, Núñez Pardo, and Téllez Téllez (2015) conducted an action research study to investigate the effects of university teachers' reflections on their personal and professional growth through the Materials Development (MD) Seminar in the Master's Program in Education with Emphasis on English Didactics (MEED). The seminar includes various reflective activities on its content and materials in relation to teachers' pedagogical practices. At the end of the seminar, a survey and a written reflection were completed by the participated teachers to see how their reflections might have influenced their personal and professional growth. Findings of this study indicated that allowing teachers to practice reflecting on the seminar materials, played a significant role in supporting them to grow in their profession, to create a reflective teaching setting, and to raise their awareness of students' needs.

\subsection{Teaching Practicum Courses and Its Use of Action Research}

Teaching practicum is an opportunity for student teachers to practice teaching in a real classroom setting. During the study of the Teaching Practicum course, these students are encouraged to conduct an action research project as it allows them to apply the acquired theoretical knowledge to an actual teaching experience (Ho, 2013). Similar to this point of view, Kasula (2015) states that teaching practicum enhances student teachers understanding of the research methodology as it integrates both theory and practice. Furthermore, teaching practicum prepares student teachers for the teaching profession through developing their knowledge and skills to teach effectively (Crookes, 2003). According to Kasula (2015), teaching practicum acts as a site for student teachers to support each other through observing and providing feedback to the practicing student teacher. By highlighting the properties of the teaching practicum, it is understood that student teachers are enabled to develop their knowledge and skills of teaching with a focus on lesson planning, managing classes, creating a teaching philosophy, and reflecting on their teaching practices (Crookes, 2003). Moreover, performing an action research project during the study of teaching practicum is a useful source for student teachers to develop professionally (Ryan, Young, \& Kraglund-Gauthier, 2017). Since the implementation of action research requires 'personal inquiry', student teachers are motivated to explore and improve their teaching practices and take actions to lead changes (Ryan, Young, \& Kraglund-Gauthier, 2017).

\section{Research Setting}

The current action research study was conducted at a Saudi Arabian University. Being a full-time student at the TESOL program is essential to fulfilling the requirements of two academic years, during which different compulsory and elective courses are covered besides a research thesis.

The Teaching Practicum course is compulsory and is taken in the second year of the MA program. This course is an opportunity for student teachers to apply the acquired theoretical knowledge in a real classroom setting (Ho, 2013). It also prepares student teachers for the qualification of the teaching profession through developing their skills to manage classes, plan lessons, observe classrooms, and reflect on their teaching practices. More importantly, the Teaching Practicum course engages student teachers in developing their understanding of 
teaching through weekly readings, classroom discussions, and reflective assignments. Presenting an action research project is considered the learning outcome of this course; therefore, this study was conducted to fulfill its requirements.

\section{Data Collection and Analysis}

To collect the data, I followed an action research design as a vehicle of reflecting on my teaching practice. Relating action research to the Teaching Practicum course is an approach towards professional development since it exposes student teachers to their teaching practices by exploring and investigating challenges to improve teaching quality (Burns, 2009). Therefore, I conducted four micro-teaching sessions in which various teaching techniques were implemented as actions to cope with the "curse of knowledge" in my classroom. During each micro-teaching session that lasted for 30 minutes, I used different resources to plan the lessons. I taught two writing lessons and two speaking lessons according to the course instructor's guidelines. Classes dedicated to micro-teaching were held on Sundays from 12 p.m. to 3 p.m. for a period of four weeks. The study involved me as a student teacher researcher and a class of an adult learner who participated in several classroom activities. This helped me to achieve in-depth insights into my teaching practice. At the end of each micro-teaching session, classroom observation and discussion were held through self-reflection, peer feedback, and the course instructor's feedback.

Lesson planning was a component of the planning phase to guide the delivery of the lesson by setting clear objectives and determining the learning materials and activities according to the allotted time. The second phase of the study dealt with carrying out a set of teaching techniques 'actions' and classroom activities that were configured towards coping with the "curse of knowledge" in my classroom. The third phase of the study involved writing a reflective journal in a form of a self-reflection writing. In doing so, I followed Newby's (2010) reflective cycle that enabled me to reflect on my teaching practice in a systematic manner. Newby's (2010) reflective cycle is a reflection model consisted of four stages; planning, acting, observing, and reflecting. In the planning stage, I planned a lesson through writing a detailed description of the lesson objectives, learning materials, and how I was going to deliver the lesson. Also, I developed a set of teaching techniques 'actions' to implement during teaching practice, in order to cope with the "curse of knowledge". Moving to the acting stage, which involved what I did in the classroom, the kind of teaching technique I used, and how the students respoded with my teaching. At the observing stage, I noticed what was happening in the classroom, were students able to achieve the lesson objectives, and they were able to complete the classroom activities. I looked for evidence to help me evaluate the success or failure of the implemented action. The reflecting stage enabled me to analyze the collected evidence and think about its findings; whether the implemented action helped me to cope with the curse of knowledge or not. If not, I had to look for another action to investigate in a new cycle.

The gathered data from the reflective journal was thematically analyzed. Thematic analysis is a method for analyzing and interpreting qualitative data into 'themes' that represent the central meaning of data items (Boyatzis, 1998). As thematic analysis is used to illustrate the qualitative 
data, it was considered appropriate for exploring my reflections during the course of the study in the Teaching Practicum module.

\section{Findings and Discussion}

Since it was difficult to avoid the "curse of knowledge" in teaching, I had to find out suitable teaching techniques to cope with it and make sure it did not hinder the classroom teaching. Communicating with students especially when giving instructions is an essential teaching skill developed through practice (Sowell, 2017). Providing clear instructions is crucial to the smooth flow of a lesson and has its impact on how well students can complete the classroom activities (Sowell, 2017). Hence, I needed to ensure that all the students had grasped the procedures to complete the assigned tasks in my lessons, as Harmer (2008) suggests "the best activity in the world is a waste of time if the students do not understand what it is they are supposed to do" (p. 37).

The following action research cycles introduced different teaching techniques 'actions' that guided me, as a student teacher, in giving instructions, which directly decreased the effect of the "curse of knowledge" on teaching.

\subsection{Action Research Cycle One}

The first micro-teaching session involved a writing lesson that was planned to form descriptive sentences with possessive adjectives, such as (my - his -her). In this session, I used a video and jumbled words for classroom activities. As a first teaching 'action' that could help me to cope with the "curse of knowledge", I planned to provide step-by-step instruction and a model to follow. As a matter of fact, there were diverse students with different levels and learning abilities within the classroom. As a result, providing this kind of guidance supported students in producing appropriate responses even with their limited competence of the target language (Harmer, 2008).

While completing the assigned tasks, I noticed that guided writing supported the students to grasp what they were expected to produce, as they had a clear vision of the targeted outcomes. Moreover, when I gave step-by-step instructions, the students were encouraged to complete the tasks gradually whom I found motivated to learn within their limits of the target language. As I was monitoring the students' performance, I could see their progress. Based on the collected evidence and my peer feedback, I realized that the involvement of the students in the learning process played a significant role in developing my understanding of the novice students' learning skills. As a result, I could illustrate the lesson content with an appropriate level of language.

\subsection{Action Research Cycle Two}

In the second micro-teaching session that was a writing lesson, students were asked to write a letter of complaint. Along with step-by-step instructions, I planned to precede teaching this lesson by teaching reading as a teaching 'action' to assist me in coping with the curse of knowledge while teaching. Therefore, two different samples of complaint letters were used as classroom activities. Brown (1987) states that students can gain in-depth insights into the topic 
and style of writing by reading and studying a variety of relevant texts (as cited in Tuan, 2012).

As a peer was participating in the classroom activities, I noticed that it was challenging to achieve the objectives of this lesson although two classroom activities were completed. Students would probably need more engaging activities to practice to being able to write a complete letter; reading and analyzing a sample letter was inadequate. It would have be better if I had used more clarifications, such as visual aids and exercises like fill in the blanks before writing the actual letter. The teaching technique 'action' that I tried in this teaching session could not help me with decreasing the effect of the curse of knowledge. During the classroom teaching, I was expecting the students to follow the sample letter and write their own letter. I explained as if the students were aware of the required skills and knowledge to write a complete letter in less than ten minutes. As another teaching 'action' for the following micro-teaching session, I planned to build the lesson on the students' prior knowledge taking into consideration their status as being novice students.

\subsection{Action Research Cycle Three}

The third micro-teaching session involved a speaking lesson that was planned to form an appropriate question for giving, accepting, and declining invitations. At the beginning of this session, I assumed that the students had limited knowledge about giving, accepting, and declining invitations in the target language. Hence, I developed this lesson upon this knowledge as another technique 'action' of coping with the curse of knowledge. Campbell and Campbell (2008) state that students' prior knowledge help them to learn by making mental connections to facilitate learning. I also used my body language, since it supported me in illustrating the meaning of specific vocabulary. With regards to the classroom activities, I used a video as the main activity besides the textbook's exercises.

While my peer was participating and following the video to complete the assigned tasks, I noticed that the students could develop their understanding by finding connections between what is being taught and their prior experience. The students had limited knowledge of particular expressions related to invitations; however, the video enhanced their learning by enabling them to form a proper question on how they would invite someone and what they would say if they wanted to accept or decline an invitation. Moreover, the use of the body language was suitable to illustrate the meaning of specific vocabulary items instead of using the native language. However, the choice of video as a classroom activity should deserve more consideration to facilitate learning and not to confuse the students. It would be helpful if the video represented a situation relevant to the students' learning. Based on the collected evidence, I realized that the students' prior knowledge supported them to achieve the targeted outcomes as long as it was supported by appropriate activities.

\subsection{Action Research Cycle Four}

The fourth micro-teaching session was a speaking lesson that was planned to enable the students to ask and answer questions related to jobs. Since visual aids were suitable to teach the basics, I planned to use 'realia' and pictures as teaching techniques 'actions' to decrease the effect of the curse of knowledge. Using visual aids is considered a useful teaching 
technique that could be employed to create an active learning environment, to facilitate teaching, and to reinforce students' learning (Shabiralyani, Hasan, Hamad, \& Iqbal, 2015). Moreover, visual aids are used to enhance students' understanding, interaction, and motivation (Danan, 1992). Instead of spending most of the class time in explaining and clarifying, I used 'realia' to present the meaning of the new vocabulary. A PowerPoint presentation with illustrated pictures and a doctor doll were used as classroom activities.

Based on my teaching practice and the course instructor's feedback, I noticed that it was suitable to use visual aids while teaching speaking skills. The students could achieve the targeted outcomes as they were fully engaged, which indicated that the used teaching technique 'action' helped me to cope with the curse of knowledge in this lesson. However, it would have been better if I had highlighted the subject pronouns (he/she) and possessive adjectives (his/her) in each question and answer, so that the students could understand the differences. Also, the jobs could have been more culturally related, so the female students could find them relevant.

\section{Conclusion}

This was an action research study that presented my reflections as a postgraduate student of MA TESOL program at a Saudi Arabian University. To carry out the study, I implemented several teaching techniques as actions that guided me in decreasing the effect of the curse of knowledge on teaching. The curse of knowledge in teaching is considered a pedagogical issue that influences the way of communicating with students, particularly when giving instructions. It referred to the teachers increased knowledge of a topic, which hinders their ability to remember what it is like to not know what they are trying to teach.

Micro-teaching sessions based on writing and speaking skills were held during a period of four weeks to get an in-depth understanding of the investigated phenomenon. Lesson planning and Newby's (2010) reflective cycle that were followed enabled me, as a student teacher, to reflect on my teaching practice systematically. As I followed Newby's (2010) cycle, I could collect data about what happened in each micro-teaching session, and then analyzed and evaluated the collected data in order to reflect on my teaching practice. The action research might introduce changes or improvement in the teaching practice to improve its overall quality.

At the end of this action research study, I can say that it helped me raise awareness of my teaching practice including my weaknesses in the classroom that I needed to work on. This action research offered me an opportunity to investigate the curse of knowledge as an everyday teaching concern that impeded the process of my teaching. I implemented several teaching techniques throughout the study so I could find solutions for tackling the issue of the curse of knowledge in my EFL classroom. Through step by step instructions, models to follow, writing through reading, students' prior knowledge, teacher's body language, and visual aids such as videos, or PowerPoint presentations were the implemented teaching techniques 'actions' during four micro-teaching sessions. The teaching sessions involved me as a student-teacher researcher and a class of an adult learner who participated in several classroom activities. Therefore, self-reflections, peer feedback, and the course instructor's 
feedback enabled me to examine the effectiveness of each teaching technique.

I could sum up the main findings in three essential points. First, dedicating enough time to planning the delivery of the lesson. Having a clear lesson plan with details of each classroom activity prevented me from going off track and helped me monitor the students' understanding. Second, the clarity of instructions played a crucial role in helping decrease the effect of the curse of knowledge during my teaching. As long as the instructions were short, simple, and precise, students were able to complete the classroom activities properly. Third, giving step-by-step instructions highly encouraged the novice students to interact with the presented content, despite their limited competence of the target language.

Although the current action research study aimed to improve my teaching practice in my EFL classroom, its main findings could apply to other teachers and researchers in the same or similar context. A significant implication of the findings is the use of action research in the EFL teaching field as it is a formative and structured process that teachers carry out to remediate problems and improve classroom practices, students learning, and institutional outcomes. Therefore, teachers are encouraged to work collaboratively on common teaching challenges they face in their classrooms. Another implication of the findings is the crucial effect of the clarity of instructions on teaching and learning. Since it is difficult to avoid the curse of knowledge in teaching, teachers need to have a clear vision about its meaning and how it affects their teaching practices and students understanding. Teachers are encouraged to think carefully about their classroom instructions and work together towards finding the most suitable teaching techniques that would help their students to follow the given instructions with ease.

Lastly, it is vital to state certain limitations that might influence the interpretation of the findings of this action research study. The current study mainly investigated the effect of the curse of knowledge on teaching productive skills, namely speaking and writing. Further studies are recommended to consider receptive skills, such as listening and reading. In addition, the limited number of the micro-teaching sessions could be a limitation of this study. Accordingly, few teaching techniques 'actions' could be implemented. To minimize the impact of this limitation, a replication of the study examining additional teaching techniques 'actions' would help to achieve a fuller understanding of the investigated phenomenon.

\section{Acknowledgement and Sponsoring information}

This action research study would not have been accomplished without Dr. Miriam Alkubaidi, the Teaching Practicum course instructor. My special thanks go to her for her continuous advice, encouragement, and guidance and more importantly her belief in me throughout this study. My sincerest thanks go to my peer for her willingness to be a part of this study. Her incessant support and feedback made this journey an interesting learning experience. Last but not least, I would like to thank King AbdulAziz University as it has offered me this learning experience.

\section{References}

Boyatzis, R. E. (1998). Transforming qualitative information: Thematic analysis and code 
development: sage.

Brown, H. D. (1980). Principles of language learning and teaching. Englewood Cliffs: Prenti ce-Hall. In: Inc.

Burns, A. (2009). Action research in second language teacher education. The Cambridge guide to second language teacher education, 289-297.

Campbell, L., \& Campbell, B. (2008). Beginning with what students know: The role of prior knowledge in learning. Mindful Learning, 101, 7-27.

Carr, W., \& Kemmis, S. (1986). Becoming critical: Education. Knowledge and Action Research. London: Falmer.

Crookes, G. (2003). A practicum in TESOL: Professional development through teaching practice: Cambridge University Press.

Danan, M. (1992). Reversed subtitling and dual coding theory: New directions for foreign language instruction. Language learning, 42(4), 497-527. https://doi.org/10.1111/j.1467-1770.1992.tb01042.x

Fakir, S. A. A. (2015). The need for introducing feflective teaching at Aden University: English language teacher treparation program. International Journal of English and Education, 4(1), 250-260.

Feldman, A., Altrichter, H., Posch, P., \& Somekh, B. (2018). Teachers investigate their work: An introduction to action research across the professions: Routledge. https://doi.org/10.4324/9781315398822

Ferrance, E. (2000). Action research. LAB, Northeast and Island Regional Education Laboratory at Brown University.

Finlay, L. (2008). Reflecting on reflective practice. PBPL paper, 52, 1-27.

Göker, S. D. (2012). Reflective leadership in EFL. Theory \& Practice in Language Studies, 2(7). https://doi.org/10.4304/tpls.2.7.1355-1362

Harmer, J. (2008). How to teach English. ELT Journal, 62(3), 313-316. https://doi.org/10.1093/elt/ccn029

Heath, C., \& Heath, D. (2007). Made to stick: Why some ideas survive and others die: Random House.

Hien, T. T. T. (2009). Why is action research suitable for education? VNU Journal of Foreign Studies, 25(2).

Ho, B. (2013). Carrying out collaborative action research in a practicum. TESOL Journal, 4(2), 295-311. https://doi.org/10.1002/tesj.59

Kasula, A. (2015). Conducting action research in a practicum: A student teacher's perspective. CATESOL Journal, 27(2), 229-237. 


\section{Macrothink}

Global Journal of Educational Studies

ISSN 2377-3936

2019, Vol. 5, No. 2

Kennedy, J. (1995). Debiasing the curse of knowledge in audit judgment. Accounting Review, 249-273.

Kuhne, G. W., \& Quigley, B. A. (1997). Understanding and using action research in practice settings. New Directions for Adult and Continuing Education, 73, 23-40. https://doi.org/10.1002/ace.7302

Lesha, J. (2014). Action research in education. European Scientific Journal, 10(13).

Mathew, P., Mathew, P., \& Peechattu, P. (2017). Reflective practices: A means to teacher development. Asia Pacific Journal of Contemporary Education and Communication Technology (APJCECT), 3(1), 126-131.

Newby, P. (2010). Research methods for education. Essex. In: Pearson Education Limited. http://dx. doi. org/10.4324/9781315834627.

Newton, L. (1990). Overconfidence in the communication of intent: Heard and unheard melodies. Unpublished doctoral dissertation, Stanford University, Stanford, CA.

Núñez Pardo, A., \& Téllez Téllez, M. F. (2015). Reflection on teachers' personal and professional growth through a materials development seminar. How, 22(2), 54-74. https://doi.org/10.19183/how.22.2.151

Richards, J. C. (1995). Towards reflective teaching. ENGLISH TEACHERS JOURNAL-ISRAEL-, 59-63.

Ryan, T. G., Young, D. C., \& Kraglund-Gauthier, W. L. (2017). Action research within pre-service teacher education. Transformative Dialogues: Teaching \& Learning Journal, 10(3).

Shabiralyani, G., Hasan, K. S., Hamad, N., \& Iqbal, N. (2015). Impact of visual aids in enhancing the learning process case research: District Dera Ghazi Khan. Journal of Education and Practice, 6(19), 226-233.

Sowell, J. (2017). Good instruction-giving in the second-language classroom. Paper presented at the English Teaching Forum.

Tuan, L. T. (2012). Teaching writing through reading integration. Journal of Language Teaching \& Research, 3(3). https://doi.org/10.4304/jltr.3.3.489-499

\section{Copyright Disclaimer}

Copyright for this article is retained by the author(s), with first publication rights granted to the journal.

This is an open-access article distributed under the terms and conditions of the Creative Commons Attribution license (http://creativecommons.org/licenses/by/3.0/). 